\title{
Experiences in New Public Management in Africa: The Case of Performance Management Systems in Botswana
}

\author{
Lewis B. Dzimbiri*
}

\begin{abstract}
In his 18-page paper entitled 'The Challenges of Governance, Public Sector Reform and Public Administration in Africa: Some Research Issues', Guy Mhone made central to public sector reforms the need to promote procedural rationality in the operation of the public sector and instrumental rationality in terms of economic, social and political outcomes. The present paper contributes to the debate on procedural rationality by focusing attention on performance management systems (PMS), which has emerged with the advent of New Public Management (NPM). It starts by providing the context of the changing role of the state since the 1980s as a background to public sector reforms in Africa. The paper further clarifies NPM and PMS as applied to the public sector before going on to discuss the experience of Botswana in public sector reforms, with particular emphasis on its performance management system. How PMS emerged, its implementation, its monitoring and evaluation are examined in this paper, along with an analysis of challenges and lessons learnt.
\end{abstract}

\section{Résumé}

Dans son article de 18 pages intitulée «Les défis de la gouvernance, de la réforme du secteur public et de l'administration publique en Afrique: Quelques thèmes de recherche», Guy Mhone a insisté sur la nécessité de promouvoir la rationalité procédurale dans le fonctionnement du secteur public et la rationalité instrumentale en termes de résultats économiques, sociaux et politiques. Cet article contribue au débat sur la rationalité procédurale, en mettant l'accent sur le système de gestion de la performance (SGP) qui a émergé avec l'avènement de la Nouvelle Gestion Publique (NGP). Il commence par indiquer le contexte de l'évolution du rôle de l'État depuis les années 1980 comme toile de fond des réformes du secteur public en Afrique. L'article clarifie en outre la NGP et le SGP

* Department of Political and Administrative Studies, Faculty of Social Sciences, University of Botswana, Gaborone, Botswana. 
tels qu'ils sont appliqués au secteur public, avant d'examiner l'expérience du Botswana dans les réformes du secteur public, en mettant particulièrement l'accent sur son système de gestion des performances. Cet examen porte sur la manière dont le SGP a émergé, sa mise en œuvre, son suivi et son évaluation, et sur une analyse des défis et des leçons apprises.

\section{Background to Public Sector Reforms in Africa}

A meaningful understanding of public sector reforms in Africa can only be achieved if one captures the role of the public sector in both the developing and developed countries and how the negative consequences of its expansion led to dissatisfaction about its size and role effectiveness in the 1980s. This, in turn, calls for a revisiting of the role and structure of the public sector. As Mhone (2003) rightly noted, the public sector represented by the executive and its bureaucracy at the federal, provincial, national and local levels together with various statutory and parastatal bodies constitutes the key apparatus for the execution of the functions of the state. Up to the 1970s, Western capitalist nations of Europe and the USA and in the developing countries of Africa, Asia and Latin America, expanded their activities in the quest to eradicate poverty and to develop their economies. In others, the state became a direct investor and provider, either because the private sector was not developed or was not willing to invest in activities that were considered critical by the state. Yet in other countries, the state expanded its activities in emulation of the socialist ideology pursued by the Soviet Union during the communist period. Private profit was considered immoral and private enterprise was seen as an instrument of exploitation and creation of disparities between the rich and the poor. Greater reliance on the public sector was also needed to check the concentration of wealth in private hands, end exploitation and ensure fairer allocation and distribution of scarce resources for development purposes (CAPAM 1996; Commonwealth Secretariat 2002).

Large-scale nationalization of indigenous and foreign private enterprises was undertaken as it was considered essential for effective development planning and the building of socialist society. The state and the public sector continued to expand, not only to develop infrastructure and provide public utilities such as water, electricity, housing and telecommunications, but also in the operation of industries, agriculture, banking, marketing and various commercial activities. Growth of private enterprise remained limited (Balogun 2003; ECA 2004). Increases in governmental activities led to a bloated public sector, and it became clear that the state was taking on far too many activities.

However, the continued poverty and economic crises in developing countries led to a realization that such a dismal state of affairs was largely 
related to poor public policies, which produced a large public sector, widespread nationalization and excessive controls over the economy. The state and its public sector undertakings had expanded beyond their capacity. Mismanagement, nepotism, political patronage, large and rigid bureaucracy, and widespread corruption became the features of public administration machinery (Turner and Hulme 1997).

Consequently, from the 1980s onwards, the state started rolling back in both developed and developing countries for various reasons, and the emphasis shifted from the state and the public sector to the private sector. Donor countries and agencies recommended reforms to developing countries in the form of Structural Adjustment Programs, which included a wide range of economic, political and administrative reforms. Economic reforms emphasized the need for liberalization of the economy by reducing controls, denationalization, privatization, private sector orientation and reliance on market forces. Political reforms, which included democratization, decentralization, increased people's participation and public accountability, had to accompany the economic reforms. In addition, administrative reforms were advocated. These included de-bureaucratization, downsizing of the public service, introduction of strong measures for combating corruption and enhancing productivity (Turner and Hulme 1997; Hughes 2003; ECA 2004). One of the main thrusts of the reforms was to reduce the direct involvement of state in economic activities, enhance the role of the private sector, create an enabling environment for the growth of the private sector and develope public-private sector partnership (Sharma 2006).

According to Mhone (2003), the stabilization and structural adjustment programs consisted of the need to promote procedural rationality in the operation of the public sector and the need to realize instrumental rationality in terms of economic, social and political outcomes. Instrumental rationality was based on views that demonstrated the superiority of market forces in the efficient allocation of resources, in order to justify the need to roll back and deregulate a number of controlled activities. Procedural rationality, on the other hand, relates to attempts to apply principles applicable to the private sector as a basis for enhancing the efficiency and effectiveness of public sector institutions (Mhone 2003).

Public sector reform initiatives in Commonwealth countries to 2002 included decentralization, commercialization, privatization, benchmarking, organizational methods, the fight against corruption, good governance, accountability, public financial management reform programmes, public sector incomes policy and administration, functional reviews, job evaluation and salary review, training, information technology, one-stop-shops, codes of ethics for public officers, strengthening management capacity, service 
delivery improvement, ICT, computerization of human resources information, performance management systems, and restructuring ministries and provinces (Ayeni 2002).

\section{New Public Management and its Characteristics}

Following the changed role of the state and growing demands for good governance globally, the New Public Management (NPM) paradigm emerged to implant a new approach into traditional public administration. It was geared toward enhancing efficiency, productivity, improved service delivery and accountability (Hughes 2003), and emphasizes a result-orientation as opposed to the process-orientation of traditional public administration. It calls for a reduction in the exclusive reliance on public bureaucracy for service delivery and advocates instead the increased use of the private sector and non-governmental organizations (NGOs) as alternative mechanisms of service delivery.

NPM advocates de-bureaucratization, offloading, downsizing or rightsizing the public bureaucracy, greater reliance on the private sector, service delivery through contracting out and outsourcing, public-private partnership, competition and reliance on market forces, and creation of an enabling environment for the growth of private enterprise. It advocates empowering rather than serving, decentralization, public participation, citizen empowerment, innovation and use of modern information and communication technology (ICT) and e-Government. It is characterized by cutting red tape, shifting from systems in which people are accountable for following rules to systems in which they are accountable for achieving results; putting customers first; empowering employees to get results, and producing better government for less (Hughes 2003; Kaul 2000).

\section{The Concept of the Performance Management System (PMS)}

As organizations are human groupings constructed to achieve specific goals, their performance is a sum total of individual employees in the organization. Traditional public administration models did not pay significant attention to the measurement of performance. Individual employees were appraised confidentially, without targets, and the approach was historical, with no opportunity to improve. Performance appraisal, as appraisal in the traditional public administration model is called, laid much emphasis on behavioural or personality characteristics such as loyalty, dependability, punctuality, honesty and so on as central attributes for evaluation of an individual employee. Individual performance was never linked to departmental, divisional and organizational strategic goals and objectives.

The urge to evaluate, measure and monitor performance of public institutions and employees has been the concern of politicians, public sector 
managers and users of public services. Consequently, interest in performance management and the need to develop appropriate performance management processes and measures has been increasing in the past two decades. As noted earlier, in an effort to improve performance, efficiency, accountability and effectiveness of public sector organizations, governments have adopted a variety of public sector reforms, and one of these is the performance management system.

Performance management can be defined as a strategic and integrated approach to delivering sustained success to organizations by improving the performance of the people who work in them and by developing the capabilities of teams and individual contributors (Armstrong and Barron 2002).

PMS is concerned with managing the organization, everyone in the business, performance improvement, employee development, stakeholders' satisfaction and finally communication and involvement (Armstrong 2003). It is based on the principle of management by agreement or contract rather than management by command. It emphasizes development and the initiation of self-managed learning process plans as well as the integration of individual and corporate objectives. It is a continuous and flexible process that involves managers and their subordinates within a framework that sets out how they can best work to achieve the required results. Its focus is on future performance planning and improvement rather than on retrospective performance appraisal. It provides the basis for regular and frequent dialogues between managers and subordinates/teams on performance and development needs.

PMS relies on performance reviews to make decisions on performancerelated pay, as well as individual/team development plans. It is also a process for measuring outputs in the form of delivered performance compared to expectations expressed as objectives, targets, standards and performances indicators. PMS links organizational vision, missions, values and strategic goals to divisional, departmental and individual goals, objectives and tasks/ targets (Henekom et al. 1987; Armstrong 2003; Hughes 2003).

\section{Public Sector Reforms and PMS in Botswana}

Since Botswana attained independence on 30 September 1966, National Development Plans (NDPs), which cover periods of five years, have functioned as instruments of guidance in the delivery of service to the nation. Ministries and departments indicate their priorities for the planning period according to NDPs, and funding is sought to carry out these plans. Though the Government of Botswana and its public service have achieved a lot since independence, problems in the functioning of the public service machinery have been noted. The public sector was viewed as inefficient, underperforming and lacking in job accountability and ownership. It was felt that it was 
insensitive to the public in terms of service provision. Wastage of resources in ministries and departments and lack of proper planning and management of funds resulted in the need for extra funding. Inefficient management of human resources led to the creation of unnecessary posts in ministries and departments.

To improve the quality of service delivered and satisfy customers and stakeholders, the government mandated the Directorate of Public Service Management (DPSM) to develop initiatives that could improve public service delivery. From 1994 to 1997 DPSM conducted investigations to see what steps could be taken to reform the public service. Changes such as Work Improvement Teams (WIT), a Performance Based Reward System (PBRS), Decentralization and O\&M Review were introduced, but the problem of poor service delivery remained. Government came up with the initiative of improving internal processes by introducing Business Process Reengineering whose recommendations included the introduction of PMS to ensure efficient and effective service delivery and the improvement and sustainability of high productivity at all levels (Ministry of Finance 2003). The sections below describe the formulation, piloting, implementation, monitoring and evaluation of PMS.

\section{Formulation of PMS}

The Botswana National Productivity Centre (BNPC) was commissioned to introduce PMS in the public service with the help of the American Consultancy Group known as the Performance Centre. Ministries and independent departments formulated strategic plans with vision and mission statements, key result areas, goals, objectives and values. These strategic plans were meant to direct ministries and departments to deliver services in a focused manner. Performance Improvement Coordinators (PICs) were appointed at each ministry to coordinate PMS.

BNPC was intended to guide the PMS process in the first year and then leave the responsibility to ministries to sustain the process in subsequent years. It was supposed to transfer the necessary skills to ministry coordinators and other staff members. The PIC force was to remain the reference group for the implementation of PMS and its role was to monitor progress, make policy decisions and provide direction on the way forward.

There was also a communication strategy in place to ensure that the process reached all parties concerned. Communication started at Office of the President level, then Cabinet and Parliament who passed information to councils. At ministerial level, ministries were expected to develop their own communication strategy to sell and sustain the PMS process (Ministry of Finance 2003). 


\section{Piloting PMS: Structure and Activities}

Before the full implementation of PMS, a pilot project was made in two ministries. The structure set up to implement the pilot project included a PIC force to oversee the process, a task force in each ministry chaired by the Permanent Secretary established to coordinate and communicate goals, objectives and standards. Members of the task force were heads of departments. For each ministry, workshops were held for the leadership. The project was to concentrate on the development of strategic plans, annual performance plans and measurement systems. Objectives of the pilot project were to promote continuous performance improvement by defining goals and objectives, creating awareness among top officials of the pilot ministries in regard to the importance of performance management. It was also aimed at upgrading the knowledge and skills of a team of senior officials in the pilot ministries. Finally, it was entrusted with the process of assisting in the rollout plan to introduce PMS to other ministries.

By the end of the pilot project, the ministries concerned believed that PMS was a tool with potential to improve productivity in the public service. The overall success of the pilot project resulted in government adopting PMS as a policy for improving the performance of the public service. Permanent Secretaries discussed and approved the recommendations of the World Bank Report on the holistic approach to performance management in 1997. This led to a cabinet decision in 1999 to implement PMS as a strategy for facilitating productivity improvement in Botswana. A document called the PMS Philosophy document was formulated by the Directorate of Public Service Management to guide the implementation of PMS (Ministry of Finance 2003).

\section{Implementation Framework for PMS}

The policy used a top-down approach because major decisions were taken by public service management and then spread down to lower management, that is, from the Permanent Secretary to the President (PSP) through Permanent Secretaries, and down the hierarchy of the public service machinery. There were four phases in the implementation processes. Phase one comprised of customization of PMS to suit individual ministries. Through the facilitation of the BNPC, ministries were able to define the best approach to introduce the system, identify resources and the implementation approach that suited them. Phase two involved the formulation of departmental Annual Performance Plans (APPs). Phase three defined the performance measurement process in terms of agreed strategic goals and objectives. Finally, phase four ensured the creation of an evaluation and review structure for PMS in a ministry or departments. 
The role of PSP, principal secretaries DPSM, PICs and ministers in the PMS implementation process were clarified. The PSP as the chief sponsor of the PMS had the overall responsibility for the successful implementation of PMS throughout the Botswana public service. Among many other responsibilities, he oversaw internal and external communication to all relevant stakeholders and key players, providing necessary infrastructure, ensuring return on investments and full accountability of the reforms by public officers. In practice, PSP delegated the implementation of PMS to the DPSM.

A number of internal committees were established to assist in the implementation of PMS. The most senior committee was the PIC Force, which consisted of Permanent Secretaries and Heads of Independent Departments and was chaired by the PSP. The Reference Committee and Technical Committee were established to manage the implementation of PMS in the public service. The responsibility of the Reference Committee was for support policy formulation and guidance, development and supervision of the implementation strategies as well as overall project management. The Reference Committee also acted as advisors to the PSP and PIC Force on issues of strategy and resource requirements. The main task of the Technical Committee was designing, developing, planning and implementation of PMS policies and strategies, along with responsibility for the utilization of resources, monitoring progress, supervision and analysis of the implementation process. The Technical Committee provided counsel to the Reference Committee.

DPSM were regarded as project managers, and their responsibility was to ensure quality assurance and value for money. Their role was to choose high-quality and experienced PMS implementers, and ensure the consistency of approach and development of all those involved in the overall implementation of PMS. It was also to provide consistent information to all key players and monitor the project to ensure that all ministries implemented PMS on time. Finally, DPSM was to provide administrative facilitation and co-management of the PMS project.

BNPC's role was to train all ministries to draw up their APPs and review mechanism and assist in the implementation of PMS and training of all PICs. BNPC was also to ensure that their consultants submitted monthly reports to the programme manager outlining progress with the ministries to which they were assigned. BNPC consultants were trained by overseas consultants to equip them with the necessary knowledge and skills to ensure facilitation of the project until its completion.

Permanent Secretaries in each ministry were sponsors for PMS and were tasked to create an enabling environment for the implementation of the PMS and oversee ministerial action plans. They were leaders of any change that occurred in their ministries. It is their responsibility to define the direction of 
the ministry by setting targets and standards of performance and ensuring accountability. They were charged with the execution of the PMS implementation plan and creating a culture of recognition and reward for performance improvement by individuals, sections, units, divisions and departments. They also were to continuously evaluate the implementation process and overall management of the project.

Ministers are required to win public and customer satisfaction within the ministry by ensuring that strategic plans are implemented. They are also accountable for reforms in the ministries as well as ensuring connection and alignment of PMS to other public reforms at national level (Ministry of Finance 2003).

\section{Monitoring of PMS}

Monitoring provides policy-relevant knowledge about the consequences of adopted policies/programmes, thus assisting policy-makers in the implementation phase. It helps to assess the degree of compliance, discover unintended consequences, identify implementation obstacles and constraints and locate sources of responsibility (Dunn 1994). Monitoring of PMS in the public service is done mainly by PICs in each ministry. Apart from ensuring capacity-building for management performance at all levels within ministries, PICs are responsible for process performance information to appraise the PSP, the minister and the Permanent Secretary on the overall performance of the ministry. The PICs also produce quarterly reports and briefings and advice on the way forward to ensure smooth implementation of the PMS (Ministry of Finance 2003).

\section{Evaluation of PMS}

Evaluation yields policy-relevant knowledge about discrepancies between expected and actual policy performance, thus assisting policy-makers in the policy assessment phase (Dunn 1994). Evaluation is the final step in policymaking and implies that the policy-makers seek to learn whether or not policies are achieving their goals, at what cost and with what effects, intended and unintended, on society (Dye 2005). The idea here is to report outputs of PMS and evaluate its impact on targets and non-target groups and also to propose changes for reforms.

The government hired Ernst \& Young Consultants to evaluate the PMS initiative in Botswana. E\&Y spoke to over 1400 officers through individual and focus group interviews in all ministries.

The three sections below draw on the E\&Y evaluation report of 2004 (GoB 2004). 


\section{PMS Outputs}

Key output is in the form of documents produced and workshops conducted.

\section{Production of Documents}

The development of strategic plans, which were not available prior to the implementation of PMS, is one of the outputs of PMS. Ministries now have working document that guide the implementation of their mandate. Again there is a Performance Management Manual in place, which provides guidance in the development of PMS. The manual supported the PMS Philosophy document (1999), which outlined the broad framework for application. There was also a document on customer care standards and service-level agreements that had been developed as a result of PMS.

Another outcome of PMS is a project called 'talking heads' where members of the public are able to talk about performance of ministries on the radio.

\section{Workshops}

Over recent years, many workshops have been conducted for officials in the public service to ensure their understanding of the operation of the PMS. It is common knowledge that most officers in the public service have an adequate understanding of the PMS philosophy and how to operationalize it. If PMS was to be evaluated in terms of knowledge of the process, then one could conclude that it has been very successful, at least judging by the number of workshops conducted.

\section{Outcomes}

The following can mentioned in terms of outcomes:

- Service delivery has improved to a noticeable level ever since the introduction of PMS

- Celebrating Productivity Convention Week has become an annual event since the advent of PMS

- Officers who were promoted to D1 level to coordinate PMS were highly motivated and their morale increased

- PMS has equipped ministries and management with more disciplined tools to manage and enhance performance and service delivery in their ministries and departments

- PMS has enhanced focus and direction in ministries and departments and made them realize their priority role in the delivery of the national development plan obligations. Through the strategic management process, ministries are able to develop clear goals and objectives, and justify their budget and funding requirements. The system has promoted a new focus on emphasizing performance and results. 


\section{Challenges}

On the other hand, there are several challenges bedevilling the implementation of PMS in Botswana. Our focus in this paper is on knowledge/information gaps, system-wide commitment, PICs problems, funding, institutional roles, authority positioning and reform fatigue, which will be addressed in turn.

\section{Knowledge/Information Gaps}

One of the key challenges experienced was the varying degrees of knowledge gaps among public servants, consultants and those who were to coordinate PMS activities in ministries and independent departments. Employees at the lower level had little or no knowledge about PMS. This might have been precipitated by the challenge of training more staff because of the geographical location and size of ministries, which resulted in staff below management level having limited knowledge about PMS, especially those outside head office. Many of the personnel charged with managing PMS had no formal project management training, and this acted as a hindrance to attaining set goals and objectives. Even the BNPC consultants seemed to have not understood all elements of PMS because the design of the project had little information available. They were all in a learning curve and swimming in a pool of confusion, just like the rest of the public service. Again, the Performance Manual, which worked together with the PMS Philosophy, did not include any specifics for practical application. This lack of specific guidelines increased the problem in ministries in terms of preparing objectives for individuals, appraisals, performance-based awards, contracts, counselling and coaching.

\section{System-wide Commitment}

It was difficult to obtain a system-wide commitment both at the level of top management and at lower echelons of the public service. For example, the consultants observed that not all Permanent Secretaries were fully committed to the philosophies of PMS. By design, top management are seen to be removed from PMS process as many of the PMS principles of planning, measurement and appraisal are not applied to the top echelons of the public service. Individuals across the hierarchy of the public service see PMS as additional work rather than as part of their jobs and this leads to non-commitment. This is exacerbated by the fact that PMS has no linkage to individual pay or reward. Little has been done to translate PMS to individual goal setting, appraisals and reward because of resistance from both managers and low-level officers in the public service. Since they were used to doing things in the same manner for a long time, officers could not easily adapt to the idea of being told to change, especially those at senior levels. This has led to PMS moving at different paces across the various ministries. 


\section{PICs Problems}

The other challenge focuses on the role and effectiveness of Performance Improvement Coordinators. There was lack of support for PICs within ministries, especially larger ones, and the geographical distribution of some offices had a big impact on their efficiency and performance. They needed additional support with regard to implementation as they did not have the required knowledge, experience and confidence to effectively implement PMS without the additional assistance or detailed framework, which was in most cases absent. PICs have other duties and tasks within their ministries and therefore have problems in trying to dedicate their attention to PMS. These additional duties put strain on PIC's and quality of their work. Finally, since there are no promotional opportunities within their structures, PICs have been demotivated in shouldering additional burden.

\section{Funding}

For any change to be institutionalized and sustained, a continuous supply of financial, human and material resources is crucial. One of the challenges faced was the level of funding allocated to DPSM. It was considered to be insufficient to complete the design of PMS. It was enough to pay for the BNPC only. Additional funding was required for external consultants to assist with the completion of the design. Ministries also required additional funding for implementation support, which was not available from BNPC.

\section{Institutional Role and Authority Positioning}

Another challenge relates to the institutional role of DPSM in the PMS divisional of labour in terms of authority over other ministries and the delegation of the PSP role to the same. The reforms unit under DPSM has a very small team to implement PMS and this means a large work commitment. DPSM experiences a dilemma in making decisions that affect the implementation of PMS because it does not have sufficient authority to influence Permanent Secretaries in other ministries regarding decisions in those ministries. Again the PSP's role in the management of the implementation of PMS, providing leadership and guidance to Permanent Secretaries and stakeholders and chairing Technical and Reference committees, was, in practice, delegated to DPSM, as noted earlier. This in effect weakened the management role of DPSM as the Director of DPSM does not have the required authority to take corrective action and influence the public service.

This is related to the consultants' observation about the spirit of competition and the territorial boundaries institutions create. PMS involved linking together initiatives such as Vision 2016 and National Development Plans. This has not been easy because those who are co-coordinating them 
have built themselves territorial boundaries to the point that they refuse to meet to agree common objectives and targets. Ministries and departments that depend on each other for delivery of mandates do not want to share objectives. The example given is that of the Criminal Justice System comprising the DCEC, Police, Attorney General and Administration of Justice, which refused to confirm one common objective on the timely disposal of cases.

\section{Reform Fatigue}

Another challenge PMS has been facing in Botswana, as in many developing countries, is the multiplicity of reforms taking place simultaneously or at times in quick succession. Public servants, facing a plethora of reforms that come one after the other within a short space of time, feel confused and end up not being committed to their implementation. For example, there are work improvement teams (WITS), total quality management (TQM), organization \& methods (O\&M), performance-based reward system (PBRS), business process re-engineering (BPR), decentralization, privatization, contractingout, performance management system (PMS) and now the balance scorecard (BSC). All these are still being implemented in the public service.

\section{Lessons Learnt}

From both the successes and challenges so far experienced in the PMS in Botswana, we can isolate the following lessons for countries that have not introduced PMS in the public service: top-level commitment and the location of the power centre, strategic plans, detailed PMS guidelines, training/effective communication, phasing out of reforms, rewards and continuous funding. These are considered in turn.

\section{Top Political and Administrative Commitment and Location of the Power Centre}

Commitment at the level of the top political leadership, such as the President, Prime Minister and cabinet ministers, is crucial for sustainability of the reforms. This has to go side by side with commitment from the highest administrative authority, like the Principal Secretary in the President's Office, the Head of the Public Service, Principal Secretaries and their immediate deputies down the administrative and professional cadre of the public service. This is also related to the need to ensure a strategic location of the reform 'power centre' in government. Reforms need to be coordinated from the Office of the President and cabinet as this office is the hub of both the political and administrative functions of the state. Delegation to other ministries needs to be avoided. The significance of culture change, starting with top management and cutting across all levels of the organizational hierarchy, is also crucial for the successful implementation of reform initiatives. 


\section{Strategic Plans}

The Botswana experience has demonstrated the importance of strategic plans to ensure an integrated approach to performance planning, implementation and evaluation. There is great value in creating a shared vision, mission, strategic goals, individual performance objectives, targets, indicators and performance reviews. Without strategic plans, there is no common focus and actions are performed at the expense of service delivery and productivity in the public service.

\section{Detailed Guidelines}

Without detailed guidelines like the PMS Philosophy document and Performance Manual to act as a reference point at every stage of the PMS, the process of formulating and implementing PMS initiative will fail.

\section{Training/Effective Communication}

It is noted from the experiences of Botswana that lack of adequate information or knowledge of the PMS both at lower and higher levels of the public service hierarchy was a major challenge to the implementation of PMS. Effective training at all levels of the public service from top to bottom as well as an effective communication strategy vertically and horizontally to ensure clarity, understanding and common focus, are all crucial.

\section{Phasing Out of Reforms}

A gradualist approach to reforms allows for implementation, evaluation and institutionalization of each reform before another is introduced. There is a far greater danger in introducing a new reform initiative before the previous reform has been understood and its value appreciated. Otherwise, there is loss of interest in reforms and even with the best intentions people will take new reforms as 'another management fad'.

\section{Funding}

An appropriate and sustained level of funding is important to ensure sustained momentum for the proper implementation of PMS initiatives.

\section{Rewards}

To succeed in PMS, there is the need to ensure that good performance is rewarded and poor performance is punished. When people realize that their performance and efforts have no bearing on their rewards, their enthusiasm to do more is curtailed. 


\section{Conclusion}

This paper has built on Guy Mhone's procedural rationality, which is aimed at enhancing the efficiency and effectiveness of public sector institutions, notably in Africa. Different countries throughout the world have experimented with various public sector reforms, such as improved service delivery, participation, human resource development, decentralization, process re-engineering, performance-based reward systems, accounting and budgetary systems, job evaluation and salary reviews, and the performance management system among others. As the paper has demonstrated, using the experience of Botswana's public sector, PMS encourages visioning and strategic management of ministries and independent departments. It facilitates and encourages open communication in the organization, which is one of the most important factors in facilitating superior performance in an organization. Through the development of strategic goals and plans, which are part and parcel of PMS, ministries are able to justify their budgets and funding requirements. There is integration in the organization, characterized by a shared vision and common values because of strategic planning. PMS has the potential to improve the performance of the public service and enhance its capacity to provide efficient service delivery to the nation. However, there remain many challenges, which relate to knowledge/information gaps, system-wide commitment, PICs problems, funding, institutional role and authority positioning, and reform fatigue.

This is not to pass a verdict about the inappropriateness of PMS in the public service. Rather, it is an attempt to draw useful lessons from the experience of Botswana in order to improve the performance of individuals, groups and organizations in the public sector.

\section{References}

Armstrong, M., 2003, A Handbook of Human Resource Management Practice, 9th edn, London: Kogan Page.

Armstrong, M. and Barron, A., 2002, Strategic Human Resource Management, London: Chartered Institute of Personnel and Development.

Ayeni, V. ed., 2002, Public Sector Reform in Developing Countries: A Handbook of Commonwealth Experience, London: Commonwealth Secretariat.

Balogun, M. J., 2003, Performance Management and Agency Governance for African

Development: The Search for Common Cause of Excellence in the Public Service, DPMN Bulletin 10(3): 19-43.

Commonwealth Association of Public Administration and Management (CAPAM), 1996, Current Good Practices and New Developments in Public Service Management, London: Commonwealth Secretariat. 
Commonwealth Secretariat, 2002, Current Good Practices and New Developments in Public Service Management, London: Commonwealth Secretariat.

Directorate of Public Service Management, 1999, The PMS Philosophy, Gaborone: Government Printer.

Directorate of Public Service Management, 2002, Evaluation of Performance Management System, Vol. 1, Gaborone: Government Printer.

Dunn, W., 1994, Public Policy Analysis: An Introduction, Englewood Cliffs, NJ: Prentice Hall.

Dye, T.R., 2005, Understanding Public Policy, Upper Saddle River, NJ: Prentice Hall.

ECA, 2003, Public Sector Management Reforms in Africa: Lesson Learned, Addis Ababa: Economic Commission for Africa.

Government of Botswana, 2004, PMS Evaluation Report, Gaborone: Government Printer.

Hanekom, S.X., Rowland, R.W. and Bain, E.G., 1987, Key Aspects of Public Administration, Pretoria: Southern Book Publishers.

Hughes, O., 2003, Public Management and Administration, 3rd edn, London: Palgrave Macmillan

Khan, M., 1981, Administrative Reform and Theoretical Perspective, Dacca: Centre for Administrative Studies.

Mhone, G., 2003, The Challenges of Governance, Public Sector Reforms and Public Administration in Africa: Some Research Issues, IDMN Bulletin X: 1-18.

Ministry of Finance, 2003, National Development Plan 9, Gaborone: Government Printer.

Sharma, K., 2006, Public Sector Management Reforms in Botswana, University of Botswana (unpublished book proposal).

Turner, M, and Hulme, D., 1997, Governance, Administration and Development: Making the State Work, Basingstoke: Macmillan Press. 